International Journal of Social Science And Human Research

ISSN(print): 2644-0679, ISSN(online): 2644-0695

Volume 04 Issue 11 November 2021

DOI: 10.47191/ijsshr/v4-i11-27, Impact factor-5.586

Page No: 3265

\title{
An Artistic Solution to A Multi-Figure Composition in the Rospis Technique of Monumental Painting
}

\author{
Adolat Khomidkhonova \\ Student, National Institute of Art and Design named after Kamoliddin Behzod
}

\begin{abstract}
First of all, let's talk about the fact that monumental painting is the oldest form of fine art. In the early days of fine arts, the first examples of monumental painting were animals and hunting scenes depicting people on the ground, on rocks, and in graphic form. Such unique and magnificent artifacts can also be found in caves in the Pamir mountain ranges in our region. Over time, the monumental works have been polished, developed and continue to evolve.
\end{abstract}

KEYWORDS: Rospis, Mosaic, Stained Glass, Sgrafito, Realistic Works, Humanism.

\section{INTRODUCTION}

The period of cultural and intellectual development in Europe in the XIV-XVI centuries, the Renaissance, along with many other arts and cultures, reached its peak in the direction of monumental painting. By this time, murals in Western Europe and Italy had developed on the basis of "humanism" - the idea of humanity. Renaissance artists such as Da Vinci, Michelangelo, and Raphael Santi in their majestic and mural frescoes are a clear example of this.

Uzbekistan, our homeland in Central Asia, has a unique idea, style, color integrity and art from the time of independence to the present day, despite the fact that it has a monumental basis of painting from ancient times. The works of Chingiz Ahmarov, Bahodir Jalolov and Alisher Alikulov, who made a worthy contribution to this, adorn the modern buildings of our country. In the paintings of Master Bahodir Jalolov, we can see how skillfully the combination of work and building found an artistic image.

\section{THE MAIN FINDINGS AND RESULTS}

So how do we find an artistic solution to a multi-figure composition? We find the answer to this question in the works of the Masters. Geometric patterns are used to solve the artistic solution of any multi-figure composition, and the tradition has survived to the present day. An important factor is the geometric structure of the composition and its integral connection with the object. Linking a mural to an object is called a synthesis process. The synthesis process is the first step in a professional approach to work. Then the proper placement of petno and warm cool colors of our wall composition, one of the main parts of the ih is done. All of the above work, as in any case, focuses on the main topic. You don't have to be limited to one or two sketches when preparing sketches. Because, as our teacher Vasily Nikolayevich Hapov said: "The first thought that comes to your mind comes to the minds of others. The more options the more innovation." It has also become easier to find an artistic solution to the multifigure composition. As mentioned below, if the artistic solution is solved by geometric structure, that is, molding, the goal will be achieved earlier and more accurately. In order to enhance the artistry of the images depicted in the century, it is necessary to have high qualifications, the necessary knowledge and a very broad outlook.

\section{CONCLUSION}

In short, with the development of modern architecture, the need for abstract works is growing, and the focus on realistic works is declining. As a result, the decorative art of monumental painting developed, and abstract works became popular instead of multifigure compositions. At this time, we need to learn from teachers in the field of traditional education, learn the artistic solution in the composition and monumental painting techniques, such as rospis, mosaic, stained glass, sgrafito, and pass it on to the next generation. Devotion to science is a great deed.

\section{REFERENCES}

1) Rustam Khudaiberganov "Monumental decorative art composition".

2) Vikipediya.

3) O.N. Samadov, History of Fine Arts. 